\title{
“It's not easy but it's still possible to be an abstainer here": Non- Drug Use Among Young Men in a Slum Area in Makassar, Indonesia
}

\author{
Sudirman Nasir ${ }^{1, *}$, Doreen Rosenthal ${ }^{2}$ and Timothy Moore ${ }^{3}$ \\ ${ }^{1}$ Faculty of Public Health, Hasanuddin University, Makassar, Indonesia \\ ${ }^{2}$ Melbourne School of Population and Global Health, the University of Melbourne, Australia \\ ${ }^{3}$ Nossal Institute for Global Health, the University of Melbourne, Australia
}

\begin{abstract}
This qualitative study explores the social context and protective factors that enable young men in a slum area (lorong) in Makassar, Indonesia, to abstain from using drugs. Semi-structured interviews, conducted with fifteen male non-drug users in the lorong showed, despite living in a drug risk environment, non-drug users were involved in neither the drug scene nor street culture. There were two main reasons for this: their employment opportunities, albeit in low paid jobs and the informal economy, and their schooling. These non-users asserted that respectability and the status of rewa (a local construct of masculinity) should and could be achieved through traditional means, i.e. employment providing legitimate income and education leading to a career. Their work provides both direct benefit, i.e. legitimate income (economic capital), and indirect benefits such as meaningful activities and structured time. Employment and schooling also generated a respectable identity (symbolic and cultural capital), wider social networks (bridging social capital) and the opportunity for upward mobility. All of these enable them to have a stake within mainstream society and are incentives for them to abstain from drug taking. This study demonstrates the crucial role of direct and indirect benefits of employment and of economic, symbolic, cultural and social capital in understanding the social context of nondrug use among young men in the lorong. The findings suggest protagonists of drug policy reform and implementation in Indonesia should be more cognizant of social marginalization in the lorong, and of the need to improve young people's access to employment and education, in order to decrease the likelihood of drug initiation and use.
\end{abstract}

Keywords: Non-drug use, young men, employment, education, capital, lorong.

\section{INTRODUCTION}

Studies on young people's drug use, both in the developed and developing world, have increased significantly (e.g. Buchanan, 2004; Hunt, Moloney, \& Evans, 2010; Mayock, 2005; Nasir \& Rosenthal, 2009a, 2009b; Nasir, Rosenthal \& More, 2011; Spooner, 2005; Stevens, 2009). Most studies focus on young people who are drug dependent and those who take drugs regularly, thus omitting the experience of young people who abstain from drug consumption. Moreover, very few have examined the experience of non-drug users and the social context of non-drug use among young people in Southeast Asia. To our knowledge, there are no studies specific to non-drug users in Indonesia published in peer reviewed and international academic journals. To respond to this void, in this study we examine the social context and protective factors that enable young men in slums, which commonly are called lorong, in Makassar, eastern Indonesia, to abstain from using drugs.

There are several reasons why it is important to examine the experience of non-drug users in slum

*Address correspondence to this author at the Faculty of Public Health, Hasanuddin University, Makassar, Indonesia; Tel: +62411585658;

Fax: +62411516005; E-mail: sudirmannasir@gmail.com areas, the lorong. First, though there are many factors that may push young people in the lorong to initiate drug use at an early age, and to escalate rapidly into drug maintenance or even drug dependence, there are still numerous young people in this locale who manage to control their drug consumption (Nasir et al., 2011) or even to abstain from drug use (Nasir, 2010). We know little about the social contexts that enable them to avoid using drugs. Second, organizations working on drug use with disadvantaged populations in Makassar and elsewhere may draw from the experience of non-drug users in the lorong to reduce the likelihood of young people initiating drug use at an early age and escalating into dependence or problematic use.

\section{Drug Use in Indonesia}

As in other countries, the consumption of moodaltering substances is not a new phenomenon in Indonesia, a country of approximately 17,000 islands, with the fourth largest population in the world and a pre-dominantly Muslim country. Though the consumption of intoxicants is strongly forbidden within Islam, the use of numerous forms of mood-altering substances, including alcohol, betel nuts, cannabis and opium, is not rare amongst many ethnic groups in the archipelago, including amongst ethnic groups in which Islam is a dominant religion (Rush, 2007). The 
Indonesian National Narcotics Board (2013) reported that cannabis is the drug most commonly used in the country, followed by heroin and amphetamine type stimulants (ATS). In addition, there is an increased availability as well as young people's greater access to party drugs such as ecstasy (Beazley, 2008). The vast majority of those who take drugs in Indonesia are young people, aged between 15 and 24 years old. A national survey in 2012 found that approximately 13 million people (6\% of the total population) had consumed illicit drugs at least once in their lifetime, 3.2 million of these $(1 \%)$ used drugs on a regular basis and approximately $25 \%$ of those regular users were heavily dependent and injecting drugs Street grade heroin (putaw) and crystal methamphetamine (sabu) is among the most common substances injected by drug users in the country (Indonesian National Narcotics Board, 2012). Like other countries in Southeast Asia, the sharing of needles and other injecting equipment is common amongst people who inject drugs (UNAIDS, 2010). It is therefore not surprising that there are numerous people who inject drugs in the country who are infected with HIV and hepatitis $C$ virus (HCV). Along with unsafe sex practices, unsafe injecting practices are the main modes of HIV transmission in Indonesia were linked to risky drug injecting practices (UNAIDS, 2010). It is in this context that, unsurprisingly, most studies on young people's drug use in Indonesia have focused on problematic and injecting drug use, overlook other patterns of drug consumption among young people and neglect young people who abstain from drug use (Nasir et al., 2011).

It is noteworthy that harm reduction programs have been running in several cities in Indonesia since 2003, however, their small scale and individualized nature have limited their efficacy (Nasir, 2006, 2010). Moreover, repressive approaches to drug use such as police raids and imprisonment still dominate Indonesia's drug policy (Fransiska, 2010). It is also worth noting that numerous studies have highlighted that tackling the risk environment and social vulnerability in poor neighborhoods is highly likely to have greater impact than oppressive approaches ((Davis, Burris, Metzger, Becher, \& Lynch, 2005; Hunt, 2006; International Drug Policy Consortium, 2010; Rhodes, Singer, Bourgois, Friedman, \& Strathdee, 2005).

\section{Introducing the "Lorong"}

The lorong chosen as the site of this study is located approximately four kilometres from the centre of Makassar and typical of many other lorong in the city, with high levels of poverty, overcrowded housing, low levels of educational attainment, high rates of unemployment and high incidence of crime, alcohol and drug use (Nasir \& Rosenthal, 2009a, 2009b). Several studies (Nasir \& Rosenthal, 2009a, 2009b; Nasir, Rosenthal \& Moore, 2011) and newspaper reports (e.g. Tribun Timur, 2012) indicated this lorong is a drug risk environment (Rhodes, 2002) in which macro-level and micro-level factors such as poverty, high levels of unemployment, low levels of educational attainment and high availability of drugs provide fertile soil for young people to engage in drug use. Chambers (1983) coined the term 'clusters of disadvantage' in order to emphasize the severe economic deprivation and social marginalisation of this kind of environment which interact to create various kinds of vulnerabilities, including the initiation of drug use at an early age and rapid escalation to drug dependence (Bourgois, 2003).

Most inhabitants of the lorong who are employed work in the informal economy or in low paid jobs (Nasir, 2010, Nasir et al., 2011). Many work in the traditional market as porters, parking lot attendants, petty traders, as becak (rickshaw) drivers, or pete-pete (mini-bus) drivers. Others are street-sellers of newspapers, soft drinks, candies, tissues, plastic bags, and other cheap items. Some inhabitants, however, work in the formal economy. They may be clerks in company offices, lower ranked public servants, shop attendants in malls, or primary and secondary schools teachers. In addition, illegal income-generating or underground economies exist, such as the selling of kupon putih (local and illegal lotto), of ballo' (local palm wine), and dealing drugs. Most people involved in these underground activities are young men, although the mass media occasionally reports cases in which women, mostly young girls or housewives, are involved (Tribun Timur, 2013).

\section{Employment, Economic, Social, Symbolic and Cultural Capital}

Several studies demonstrate the crucial role of manifest and latent functions of employment (Paul \& Batinic, 2010; Paul et al., 2007; Paul \& Moser, 2006, 2009; Stevens, 2019) and of economic, symbolic, cultural and social capital in enabling young people to avoid involvement in risk-taking behaviours, including severe engagement in drug use (Dillon, ChiviteMatthews, Grewal, Brown, Webster, Weddell, \& Smith, 2007; Hunt, 2006; Nasir, Rosenthal \& Moore, 2011; Walburton, Turnbul, \& Hough, 2005). Jahoda (1981, 
1992) argued that work does not simply generates manifest function or direct benefit, i.e. income, but also produces latent functions or indirect benefit in the forms of gainful activities, structured time, positive status and identity, collective purpose, as well as wider social contacts (Jahoda, 1981, 1997). Manifest and latent functions of work contribute to improve and maintain an individual's physical health, mental health and social wellbeing, thus preventing social exclusion and facilitating a stake within mainstream society (Paul \& Batinic, 2010; Paul et al., 2007; Paul \& Moser, 2006, 2009; Nasir et al., 2011).

Bourdieu played a key role in developing the concepts of different types of capital; economic, symbolic, social and cultural. He defined economic capital as the financial means generated through productive activities such as employment to earn income and assets, to meet both necessities and luxuries of daily life (Bourdieu, 1986). Symbolic capital is explained as an overarching resource available to an individual on the basis of honour, prestige or recognition as a culmination and the result of cultural, economic and social capital (Bourdieu, 1986). Furthermore, Bourdieu stressed the roles of recognition, reputation and prestige as essential components of symbolic capital: "struggle(s) for recognition are a fundamental dimension of social life and ... what is at stake is the accumulation of a particular form of capital, honour in the sense of reputation and prestige" (1999, p. 22). Bourdieu also defined cultural capital as legitimate competence and credential generated from individuals' prolonged and persistence activities, through training and educational attainment, which might promote upward social mobility beyond economic means. Finally, Bourdieu maintained that social capital is generated from group membership, affiliation and social networks and through meaningful relationships with other people or institutions.

Confirming some of Bourdieu's assertions on social capital, Putnam (1993) argued social capital combines individual action and social structure such as norms, expectations, obligation as well as trust and the sharing of information and networks, which can be both productive and destructive. Putnam (2000) also introduced two subtypes of social capital; bonding social capital and bridging social capital. Putnam states that whilst bonding social capital tends to be demonstrated as exclusive and more inward-looking group identities, bridging social capital manifests as more inclusive and outward-looking group identities.
Put differently, bonding social capital acts as superglue to keep us connected with our own group whereas bridging social capital acts as a social lubricant to facilitate interaction with people beyond our innate group. Studies indicate the potential benefit of bridging social capital that may facilitate social inclusion and upward social mobility, and the potential negative impact of some sources of bonding social capital which may exclude, marginalise, constrain and entrap young people, particularly those who live in urban poor areas (Barry, 2006; Woolcock, 2001), including in involvement in risk taking practices such as crime and drug use (Nasir, 2010; Nasir \& Rosenthal, 2009a, 2009b)

There are several differencies between Bourdieu and Putnam in theorising social capital. Putnam's perspectives on social capital is frequently categorised as communitarian approach of social capital and view social capital as a collective attribute of a group of people or community. Bourdieu's framework on social capital mostly based on sociological perspectives i.e. sociology of conflict and power relation (Blackshow and Long, 2005). Despite these differencies, both have significantly contributed in developing and disseminating theories on capital. Blackshow and Long (2005) stated that Bourdieu offers a more insightful and critical analysis linking symbolic and economic capital. Moreover, Bourdieu's framework incorporates qualitative approaches and attempts to allow the voices of the oppressed to be more heard (Blackshow and Long, 2005).

\section{METHOD}

This qualitative study was part of a larger project exploring the experience of 45 young males in the lorong with differing levels of involvement in drug consumption i.e. problematic drug users (those who are drug dependent), controlled drugs users (those who consume drugs in controlled ways) and non-drug users (those who do not take drugs). Fifteen participants fitted the category of non-drug users, i.e. they abstained from drug use, refused offers to use drugs, or had tried cannabis on one or two occasions and ceased their experimentation (Dillon, ChiviteMatthews, Grewal, Brown, Webster, Weddell, \& Smith, 2007; Nasir, 2010). Semi-structured interviews were conducted with non-drug users to explore the social context and protective factors which provide incentive to abstain from drugs.

Informants were recruited through snowball or chain sampling. They were recruited at several 'hanging-out' sites in the lorong. Interviews incorporated questions 
about informants' social world (e.g., their employment, education and marital status, their daily lives and social interactions), a history of their risk-taking behaviours (if any), and for non-drug users, factors that enable them to abstain from drugs and refuse drug offers. All interviews were tape-recorded, conducted in Indonesian language by the first author, transcribed verbatim and translated into English.

We employed a thematic approach to analyse interviews transcripts (Green \& Thorogood, 2004). The interviews were coded and categorized by the first author to create a system of thematic classification. An intensive and systematic reading and coding of the transcripts allowed major units of classification (issues, themes and concepts) to emerge. In addition, systematic reading, re-reading and coding ensured issues, themes and concepts were sensitive to the informants' narratives. This procedure allowed an inductive process to take place i.e. condense extensive and varied raw data into a brief, summary format; establish clear relationships between themes that emerged from the raw data and develop a concept about the importance of the social and economic context in facilitating young people's non-drug use. Interpretive and reflexive analysis (Green \& Thorogood, 2004) yielded a theoretical explanation of the social context of their non-drug use.

Ethics approval for the project was obtained from The University of Melbourne. Informants were assured of confidentiality and no identifying information was collected; pseudonyms have been used in this paper. We also obtained permission and support to conduct the project from the South Sulawesi Commission on HIVIAIDS and the South Sulawesi Narcotics Board.

\section{FINDINGS AND DISCUSSION}

\section{Negotiating Drug Abstinence in a Drug Risk Environment}

All fifteen non-drug users were either employed or at school at the time of data collection. Thirteen were employed in low-paid jobs in the informal economy, one was a senior high school student, and another was pursuing a degree at a state university in Makassar. Two were married with children. All were born and grew up in the lorong in the context of economic deprivation and a drug risk environment.

\section{Three Categories of Non-Drug Users}

The experience of these non-drug users was not homogenous and they expressed various forms of negotiation with the drug risk environment in the lorong. Three categories of abstainers emerged: those who had never experienced direct drug offers and had never consumed drugs; those who had experienced direct drug offers but had never used drugs; and those who had experienced direct drug offers and had used chimeng (cannabis) on one or two occasions and then decided not use it again.

Only one informant stated he had no experience of direct drug offers. He mentioned his personality, his limited contact with other young people in the lorong, the fact that he showed no interest in using drugs as well as his appearance as possible reasons why those who take drugs in this locale showed less interest in offering him drugs:

None have directly offered me drugs. Possibly because I always walk fast to leave the lorong when I go to school and I keep trying to avoid the spots where young people usually hang out and smoke [cigarette], drink [alcohol] or take drugs. Or maybe because I'm just small and seem like an innocent boy so those who use drugs in the lorong and at school think I'm not a good target ... Maybe they don't see any hint that l'm interested in taking drugs. Indeed, I never imagine myself using drugs or drinking [alcohol]. I don't even smoke cigarettes. (Sandi, 18 years)

In contrast, twelve young men had received direct drug offers but had never taken drugs. Most smoked cigarettes and occasionally drank alcohol. This, as well as their regular contacts with other young people in the lorong, facilitated direct drug offers to them or made it extremely difficult to avoid such offers:

It is nearly impossible to avoid drug offers if you frequently hang out with other young people here. Moreover, I smoke cigarettes and drink [alcohol] occasionally with my friends in this lorong. You know, some of them smoke chimeng [cannabis] or take boti [benzodiazepine]. Several times they have offered these drugs to me but l'm not into drugs. I just prefer my cigarettes and alcohol. Both are enough for me. (Sapri, 24 years)

Unless you don't socialize with other young people in the lorong, or you just 
stay in your house most of the time, you cannot avoid drug offers. I cannot stay inside my house all the time and I cannot live here without hanging out, having a chat, drinking coffee or occasionally drinking [alcohol] with my friends. Many of them smoke chimeng but they know and respect my rule. They know l'm not interested in drugs and I never take them. In the past some of my friends offered me drugs like chimeng or koplo [benzodiazepine] but I stuck firm to my stance not to take drugs. Finally, they give up. Now they just leave me with my cigarettes when they smoke their chimeng. (Madi, 21 years)

Two young man reported that they had received drug offers and had experimented with chimeng (cannabis) on one occasion. They had then decided not take it again. Their frequent contact with other young people in the lorong, their curiosity and desire to be considered rewa (a local construct of masculinity) when they was younger made it particularly difficult to avoid being offered drugs. However, they mentioned the feelings of discomfort after taking cannabis and the absence of any pleasurable effects as their reasons for not continuing using this drug. Udin (19 years) said:

I tried chimeng twice. But that happened a long time ago, when I was about thirteen or fourteen and it was not something extraordinary. We experimented with cigarettes, alcohol and chimeng. You know, like other boys, I wanted to be seen as a rewa boy. But I found cigarettes and chimeng are not for me. I can drink [alcohol] occasionally but I can't smoke either cigarettes or chimeng. Initially some of my friends teased me that I'm not as rewa as them, I'm a sissy and so on, but I ignored them and said I don't need to prove myself through things that I don't like and I don't find it enjoyable ... I don't know, I just don't find any pleasurable effects from chimeng or cigarettes. They just made me cough and caused a sore throat. In fact, I find drinking [alcohol] is more fun and relaxing.

The concept of rewa refers to toughness or braveness as vital markers of masculine identity in Makassar. It is a popular notion of masculinity particularly among boys and young men in the lorong. Several studies in Makassar have explored rewa and its relation to young people's risk-taking practices such as involvement in gangs, violence, petty crime, drug dependence and drug injection as well as in practices to regulate drug consumption in order to prevent drug dependence (Nasir, 2006, 2010; Nasir et al., 2011; Nasir \& Rosenthal 2009a; 2009b). Furthermore, Nasir et al. (2011) found that though rewa is more frequently linked with engagement in risk taking practices, several young people also linked it with more traditional and positive aspects of masculinity such as having a job and career.

\section{Factors that Facilitate Employment and Remaining in School}

All non-drug users in this study were either employed or at school. Most stated that their individual agency, their ability to delay gratification, and the presence of adult role models who are employed, were essential factors making them determined to work even if only in the informal economy and in low-paid jobs. Furthermore, instead of seeking instant gratification and trying to achieve the status of rewa through risk-taking practices, they preferred to accomplish this through conventional means such as employment and financial independence:

I sell fish in a market not far from this lorong ... Members of my family are not wealthy but they're hard-working people, though they mostly work in low-paid jobs. They kept reminding me that if I decided to leave school early l'd have to work. They always say if you're in your twenties and you cannot support yourself, you're actually not a man. You're not rewa. You have no siri' [dignity] and you're merely a lazy and parasitic person. You don't deserve any respect if you're not independent financially or if you don't earn your own halal [legitimate] money ... I believe that having a job and halal income are signs of a rewa man. In fact, being involved in a gang, using drugs and doing bad things are not actually rewa, these are just pongoro' [stupid activities]. You can see, most of them end up as addicts, unemployed and criminals. (Muna, 20 years)

Courage, persistence, family support and aspiration for gradual upward social mobility were also 
mentioned, by those abstainers who were still at school, as the main reasons to continue their education:

I'm lucky I have an opportunity to have my secondary education at a prestigious high school. Not many poor young people like me can be accepted into this school. So, I won't waste my opportunity. I'm now trying my best to graduate with excellent marks so I can be accepted at Hasanuddin University or at other state universities in this city ... I also hope that with excellent marks at secondary school I can have a scholarship for my tertiary education ... I think graduating from a reputable university with excellent marks and then having stable employment is the only chance I have to improve my life and to help my family. And this is also the best way to prove that I am a man, a real rewa man. (Sandi, 18 years)

One young man, who was currently studying at university, stated:

Even my brothers used to tease me when I said l'll go to university. They laughed at me. Maybe because actually I was not too different from other lorong boys when I was at junior high school, I mean I hung out, played with them and experimented with cigarettes and alcohol, though I had never taken drugs. At the time I even participated in several brawls to defend our lorong. Like others, I wanted to be seen as a rewa boy. But looking at those who just hang out, are unemployed and are involved in bad things [crime] made me think deeply and I said to myself I don't want to end up like them. Some of them teased me and called me mommy's sweet kid (laugh) but I ignored them. Thank God, I like to read books, I like to study and I managed to be accepted to the university. My uncle supported me financially for my tertiary education. Now I also receive a scholarship at the university. Moreover, I work at an internet café to have a bit of pocket money. I'm studying and working hard. I know, this is my only chance and I won't waste it. (Dudi, 23 years)
These narratives of abstainers who have jobs or who manage to continue their study revealed their perseverance, courage and willingness to delay gratification in order to achieve progress and betterment in their lives. These qualities are among those essential in order to accomplish gradual upward social mobility (Blanden, Goodman, Gregg, \& Machin, 2004; Blanden, Gregg, \& Macmillan, 2007).

\section{Direct and Indirect Benefits of being Connected to Employment and to School}

Consistent with the findings of other studies (Dillon et al., 2007; Jahoda, 1982, 1997; Kim \& Zane, 2002 Paul \& Batinic, 2010; Paul et al., 2007; Paul \& Moser, 2006, 2009), abstainers who were employed or at school reported direct and indirect benefit that accrued from their determination to work or to continue their education. They acknowledged that through work or study they were able to establish a positive identity and a good reputation as well as supportive and meaningful relationships with their family, their neighbours and others both within and outside the lorong:

If you work hard everyday to earn halal [legitimate] money for your family, you'll have a good reputation in the lorong. They respect you because they see you work hard. They see that you don't waste time just hanging out and doing nothing like those who are unemployed, and they see that you don't engage in bad things [crime]. If you go to work every morning to feed your family and you don't cause any trouble, people will respect and treat you as an adult man. Your family will also respect you because you support them financially and they're proud of you because of your good reputation ... Moreover, if you work you will know and interact with many people and knowing more people will bring good things including more income or better opportunities. (Sapri, 24 years)

The experience of employed abstainers revealed their access to economic capital and to more viable and sustainable symbolic capital (Barry, 2006; Bourdieu, 1986) that resulted from their employment, including respect and positive identity as well as wider contact with people both within and outside the lorong. Moreover, their wider contacts, particularly with those from higher socio-economic background, potentially 
facilitate social inclusion as well as provide broader bridging capital that could assist them to better their lives (Putnam, 2000; Woolcock \& Sweetser, 2002).

In addition, the narratives of abstainers who have continued study, particularly those who were studying at university such Sandi and Dudi, indicated their potential to generate legitimate cultural capital (Barry, 2006; Bourdieu, 1986, 1990) derived from their tertiary education. Cultural capital may manifest as sufficient educational attainment and academic qualification, positive currency and reputation, broader social networks, and wider opportunity as well as optimistic characters indicated by solid aspiration and efforts to accomplish upward mobility (Bourdieu, 1986; Woolcock \& Sweetser, 2002).

\section{Factors that Facilitate Abstaining from Drug Use in a Drug Risk Environment}

As shown in other studies (Dillon et al., 2007; Hawkins, Catalano, \& Miller, 1992; Spooner, 2005), there are multiple factors which may influence young people's decision not to use drugs. Abstainers in this study addressed several underlying non-mutually exclusive factors that enabled them to avoid drugs. These related to their lifestyle aspirations and relationships, and their fear of the physical, psychological, legal and social impacts of drug use.

\section{Factors Related to Lifestyle Aspirations and Relationships}

Consistent with prior research (Dillon et al., 2007; Hawkins et al., 1992; Piko \& Fitzpatrick, 2004; Spooner, 2005), non-drug users highlighted the influential roles of their career aspirations, as well as the disapproval of their families, close friends or teachers, as their major reasons to abstain from drugs. To some extent these led them to weigh the cost versus the benefit derived from taking drugs:

I have a good reputation and a good relationship with my family because I'm a diligent student. Therefore I won't let them down by using drugs. They will be very upset if I take drugs. I also know that using drugs will highly likely harm my study and my dream to graduate with excellent marks. Taking drugs will potentially threaten my chance to have a scholarship and to continue my study at a university ... In short, I don't see any benefits for me if I take drugs. Instead of gaining benefits, I'll suffer from many bad consequences. (Sandi, 18 years)

Muna (20 years) mentioned the crucial role of his employment as well as his religiosity (Piko \& Fitzpatrick, 2004; Sekulic, Kostic, Rodek, Damjanovic, \& Ostojic, 2008) in preventing him from using drugs:

I don't see any point ruining my reputation by using drugs. If I use drugs, people and my customers may be reluctant to buy my fish. Thus l'd risk my job and my income. Moreover, people in this lorong know me as a hard working and religious man. I always go to the mosque to pray. Sometimes I act as imam [the leader of the prayer]. I feel good with these and people respect me. I won't put these [valuable] things at risk by taking drugs. I also believe that using drugs and other toxicants is haram [forbidden] in Islam.

Additionally, non-drug users highlighted their views that purchasing and consuming drugs was a waste of money:

Drugs are expensive. For me using drugs is a waste of money. You know, I have very limited pocket money and I prefer to spend it on other things. In fact, even for things that I really like such as good shoes, good shirts, good jeans, DVD, books and so on, my money is far from enough ... I think those who take drugs regularly waste a lot of money. You cannot depend on your friends to offer you free drugs all the time. Most likely you have to pool money to buy drugs and I don't see this as a good reason to spend my little pocket money. (Dudi, 23 years)

Sandi (18 years) emphasised his structured time, the nature of his busy life and the harmful nature of drugs as influences on his decision not to use drugs:

I'm busy studying, reading books or doing other things in my house or at school. I can have fun without drugs and I think I simply have no time for useless and harmful things like taking drugs. You know, taking drugs is only suitable for those who have no other meaningful things to do, and that's not me. 
It is noteworthy that being employed or at school and having an aspiration for upward mobility, a respectable identity, wider social networks and meaningful relationships with their families and with people both within and outside the lorong generated a sense of self-fulfilment, control and power that, in turn, provide an incentive to abstain from drugs:

Having a job makes me feel good and prevents pessimism. I know it's not easy and it's not going to lead me to a more decent life instantly but with my job at least I can provide decent food and clothing for my self and my family. If I keep working, serving my customers well, save money cent by cent, seeing and using every opportunity, and avoiding risky things like using drugs, InsyaAllah [God willing] gradually I'll have a better life. (Sapri, 24 years)

Being a university student is a luxury for most lorong boys. That's why I won't waste this luxury by doing useless things like taking drugs. I know finding a good job nowadays is not easy event for those who have a university certificate. But I'm not a pessimist. I've seen that even those people with limited education can survive as long as they're willing to do any kind of halal [legitimate] job. I'm ready to start at the bottom too. With my university certificate and my networks I'm sure I'll find a decent job and gradually have a better life. I won't ruin my opportunity and my aspiration for a better future by using drugs. (Dudi, 23 years)

As can be seen from the above narratives, non-drug users' employment enables them to have regular and halal (legitimate) income (economic capital), achieve a more constructive masculine (rewa) identity (that can be categorised as symbolic and cultural capital) as well as to establish meaningful relationships with their families and with a wider range of people in the lorong. Their employment as well as their education (for a few) also assist them to achieve a respectable identity and allow them to maintain broader social networks with people from higher socio-economic backgrounds, both within and outside the lorong, and therefore enable them to be more socially included. Their employment, educational attainment, positive identity, meaningful relationships and wider networks therefore generate not just bonding social capital but also bridging social capital (Barry, 2006; Walbuton, Turnbul, \& Hough, 2005) as well as symbolic and cultural capital (Bourdieu, 1986). These enable them to avoid severe forms of social exclusion and allow them to have a stake in mainstream society. These in turn play an influential role as protective factors (Hunt, 2006; Walburton et al., 2005) against involvement in drug use and empower them to apply multiple strategies to refuse drug offers and to abstain from drug consumption.

\section{Fear of Physical, Psychological, Legal and Social Consequences}

As in other studies (Dillon et al., 2007; Hawkins et al., 1992; Sekulic et al., 2008; Spooner, 2005), nondrug users in the lorong feared the physical, psychological and social impacts of drug use, including health consequences. These significantly influenced their decisions not to use drugs:

I'm afraid of getting sick if I take drugs. In fact, even the smell of cigarettes makes me dizzy let alone chimeng or other drugs. I mean for the longer term, the impacts of drugs must be fatal ... I want to stay healthy and fit so I can keep working. You know, if you're in ill health, the cost of treatment at hospital is very expensive. (Nandi, 19 years)

These young men maintained that their fear of stigma, of losing control and of addiction helped them to abstain from drugs. Most provided gloomy pictures of problematic drug users whom they despise:

Look at those pecandu [addicts] in this lorong. They lose control. In fact, they're controlled by drugs. It seems there's nothing else in their heads that is more important than drugs ... I think heavy drug use led them to end up out of work for a long time and then became involved in crime to support their habit. These only take them either to jail or to hospital. As a matter of fact, I don't use drugs because I'm afraid of losing control and being enslaved by drugs. (Madi, 21 years)

Fear of legal and social consequences of excessive drug use were also mentioned as major reasons enabling them to abstain from drugs: 
Most of those who use drugs excessively have troubles with the police. You know, most of them also engage in bad things [crime]to support their habit. Once you're arrested by the police you have a criminal record. This will impede your opportunity to have a good job. In fact, you can't apply for a good job if you have a criminal record. (Dudi, 23 years)

Sapri (24 years) addressed in greater detail the social impacts of excessive drug use including the risk of being trapped in a vicious cycle of addiction, crime, and unemployment:

I have seen the misery of many young people who take drugs heavily in this lorong. I have seen the fact that being an addict frequently means being trapped in a vicious cycle of bad things and it's very difficult to escape from this cycle ... Look at them closely. Most if not all of them are unemployed, engage in crime to support their addiction and have problems with the police. I know some of them, including my own cousins, have tried hard to get off and stay off drugs but have been sucked back again and again, have relapsed again and again. This is because they have been attached too strongly to the wrong crowd and cannot move on. Moreover, no decent people are happy to stay in contact with these kinds of people. Because they have made much trouble in this lorong and that's why they mostly interact with their fellow addicts and criminals ... In short, they're trapped and it's very hard to free themselves from this trap because they've gone too far.

\section{Strategies for Refusing Drug Offers}

There are two strategies used by abstainers for refusing drug offers. One is proactive, by avoiding drug-related situations, and the other reactive, by firmly saying 'no'. Sandi employed the first strategy:

I always try to avoid those who use drugs. I usually walk fast when I go to school and when I go back to the lorong. I mostly stay in my house and spend very limited time socialising with other young people here. Now I mostly spend my time outside the lorong. I have many activities at school including participating in making a monthly school bulletin. I can say I don't have many friends in the lorong. Actually, most of my closest friends are my classmates at school. (Sandi, 18 years)

Others employed the second strategy by directly but politely saying 'no' to drug offers:

I just say 'no' to those who offer me drugs. But I always refuse it in a firm bu still polite way. They know I'm not keen on taking drugs. I usually say, smoking cigarettes or drinking coffee or drinking a bit [of alcohol] is already enough for me. As I said, most of my friends who use drugs respect my stance. In the past some of them teased me as sissy or a kawe-kawe [transvestite] but I just laughed and ignored their ridicule. In the end, they stopped teasing me and accepted the fact that I'm not interested in taking drugs just to prove myself as a rewa [masculine] man. (Sapri, male, 24 years)

However, refusing can cause awkwardness. Nandi (19 years) said:

Actually sometimes I feel a bit awkward, like being uncomfortable because frequently I'm the only one there not taking chimeng [cannabis] or boti [benzodiazepine]. I mean, it's not rare I'm the only one just smoking cigarettes or drinking a bit [of alcohol] ... Fortunately l'm good at making jokes and singing so overall I can overcome my awkwardness. I find my jokes and my songs work well to keep our hanging out warm and make them forget that I'm the only one there who does not use drugs (laugh).

The narratives of abstainers who experienced drug offers and refused them confirm other studies that addressed the possible consequences, including ridicule and awkwardness, that may arise from rejecting drug offers (Dillon et al., 2007; Hawkins et al., 1992; Nasir, 2010; Spooner, 2005). Furthermore, Dillon and colleagues (2007) highlighted that social and interactional skills such as assertiveness and a good sense of humour, may improve young people's capability to negotiate the drug risk environment and refuse drug offers. 


\section{Perspectives on Drugs and those who Use Drugs}

Despite their decision to abstain from drugs and to refuse drug offers, non-drug users expressed differing views toward drugs and toward people who use drugs. Those who had never experienced drug offers and had limited contacts with drug users in the lorong maintained that all kinds of drugs and all patterns of drug use are dangerous:

For me all drugs, even chimeng [cannabis], are dangerous in the long term. I feel sorry for those young people who need drugs to have fun. Taking drugs is a waste of money and a waste of time. Taking chimeng will lead you to other drugs ... This off course is my personal view. At the end of the day, everybody has their own choice. (Sandi, 18 years)

Those abstainers who had experienced drug offers and regularly interact with drug users in the lorong had a more nuanced perspective toward different drugs and differing levels of drug use:

I have some friends who use drugs but none of them use putaw [street-grade heroin]. Moreover, most of them have jobs. They're not addicts. They're not dependent on drugs. They're totally different from those pecandu [addicts], those penganggur [unemployed], and those who engage in bad things or those who do nothing other than using drugs ... That's why many people say that being unemployed and using drugs heavily is a deadly combination. You know, they don't have anything to lose so let themselves be enslaved by drugs. (Muna, 20 years)

\section{Positive Deviance: Being Connected to Work and School as Protective Factors}

As long as you keep yourself busy with useful activities, I'm sure it's still possible to be an abstainer here. It's not easy but it's possible. As long as you're strong enough to be different, to be the odd one out, as long as you can stand the ridicule that you're not a rewa boy, you're a mommy's sweet kid, a sissy, a kawe-kawe [transvestite], a gay or whatever they like to call you. I've experienced all of those mockeries but I don't care. I stay firm and I won't use drugs. I have many other better things to do and I aspire to finish my study and then have a good job. Using drugs won't help me achieve these. In short, I just don't see any good enough reason to take drugs. (Dudi, 23 years)

Dudi and other abstainers in this study can be categorized as positive deviants (Spreitzer \& Sonenshein, 2003). They have succeeded in deviating from the norms among most young people in the drug risk environment in the lorong, resulting in a positive outcome. Their courage to negotiate the drug risk environment in the lorong as well as their connection to employment and to school are influential in generating protective factors that enable them to abstain from drugs and to assist them to refuse drug offers (Dillon et al., 2007; Hawkins et al., 1992; Kim \& Zane, 2002; Nasir 2010; Spooner, 2005). To some extent their experiences reinforced Spreitzer and Sonenshein's argument that "courage provides individuals with the backbone to engage in positively deviant behaviours" (2004, p. 217).

\section{CONCLUSION}

We have presented the experiences of non-drug users in the lorong, including the social context and protective factors that enable them to abstain from drugs and to refuse drug offers in a drug riskenvironment (Dillon et al., 2007; Hawkins, et al., 1992; Hunt, 2006; Kim \& Zane, 2002; Mayock, 2005). In line with the sociological concept of manifest and latent functions of employment, as well as the concepts of economic, symbolic, cultural and social capital, we argue that young men's employment and educational attainment may play an essential role in facilitating incentives for them to refuse drug offers, to abstain from drug taking and to distance themselves from deeper participation in street culture and risk-takin $g$ practices.

In addition, instead of being passive and trapped in the limited opportunities and networks within the lorong, non-drug users in this study are determined to transcend their disadvantage and to pursue upward social mobility through their employment and education. Being attached to employment (Jahoda, 1982, 1997; Paul \& Batinic, 2010; Paul et al., 2007; Paul \& Moser, 2006, 2009) and to school (Dillon et al., 2007; Kim \& Zane, 2002; Rivers et al., 2006) enables these young men to have legitimate income (economic capital), good reputation and respectability (symbolic capital and cultural capital), wider networks or bridging social capital (Woolcock, 1998, 2001; Woolcock \& 
Sweetser, 2002), and to have a stake in mainstream society. These, in turn, allow them to detach themselves from participation in a harmful street culture and risk-taking practices in the lorong, including engagement in drug use. Young men in this study are examples of positive deviants.

We acknowledge that the small, convenience sample recruited for this study limits generalisability. It is with this caveat in mind that we interpret the narratives of the young men in our study. However, the experiences of young men in this study have shown their capacity to negotiate with the drug risk environment in the lorong. This may be utilized to improve drug prevention programs in this locality.

The experience of non-drug users in this study has also highlighted the importance of broader efforts to tackle structural vulnerability in urban poor neighbourhoods like the lorong. It is important to increase social support for young people to enable them to have access to income, meaningful activities, structured time, positive identity, wider social networks and opportunity for upward mobility that could be obtained trough jobs and education, as an integral part of drug policy. It is imperative that drug prevention for young people in low-income neighbourhoods be linked to rights and development perspectives and campaigns for social opportunity, social welfare and social equality. This study confirmed the findings of previous researchers (Dillon et al., 2007; Hawkins et al., 1992; Spooner, 2005) who maintained these are protective factors from drug use.

Nevertheless, increasing social support to enable young people in low-income neighbourhoods to remain at school and pursue higher study, as well as enhancing their capabilities to have better access to employment, is not a panacea. This will not eliminate drug use and drug-related harms in these kinds of environment. However, such support potentially reduces structural vulnerabilities among these young people, facilitates social inclusion or integration within mainstream society and potentially facilitates or strengthens protective factors. It also would improve their ability to negotiate better with the drug risk environment in these locales. Furthermore, such social support is potentially useful to assist young people's transition into gainful and independent adult life.

\section{CONFLICT OF INTEREST STATEMENT}

No author has any financial or personal relationships with people or organisations that could inappropriately influence (bias) the research.

\section{ACKNOWLEDGEMENT}

We would like to express our gratitude to the young men who participated in this study. We also thank to the Faculty of Medicine, Dentistry and Health Sciences and Nossal Institute for Global Health, The University of Melbourne, as well as to the Provincial Government of South Sulawesi and to the City Government of Makassar who generously provided fellowships that enable Sudirman Nasir to conduct fieldwork in Makassar.

\section{REFERENCES}

Aggleton, Peter, Andrew Ball and Purima Mane. (Eds). 2006. "Sex, drug and young people". London and New York: Routledge.

Barry, Monica. 2006. "Youth Offending in Transition: The search for social recognition". Abingdon: Routledge.

Beazley, Harriot. 2008. "I love dugem: Young women's participation in Indonesian dance party scene". Intersections: Gender and Sexuality in Asia and the Pacific 18, October. http://intersections.anu.edu.au/issue18/beazley.htm

Blackshaw, Tony and Timothy Long. 2005. "'What's the Big Idea'? A Critical Exploration of the Concept of Social Capital and its Incorporation into Leisure Policy Discourse", Leisure Studies, 24 (3): $239-258$

http://dx.doi.org/10.1080/0261436052000327285

Blanden, Jo, Andrew Goodman, Paul Gregg and Stephen Machin. 2004 "Changes in intergenerational mobility in Britain, in (M. Corak, ed.), Generational Income Mobility in North America and Europe". Cambridge:Cambridge University Press. http://dx.doi.org/10.1017/CBO9780511492549.007

Blanden, Jo, Paul Gregg and Lindsey Macmillan. 2007. "Accounting for intergenerational income persistence: non-cognitive skills, ability and education". Economic Journal, 2(4), 117-122

Bourdieu, Pierre. 1984. "Distinction: A social critique of the judgement of taste". (R. Nice, Trans.). Melbourne: Routledge \& Kegan Paul.

Bourdieu, Pierre. 1986. "The forms of capital (R. Nice, Trans.). In I. C. Richardson (Ed.), Handbook of theory and research for the sociology of education". Westport, CT: GreenwoodPress.

Bourgois, Philippe. 2005. "In search of respect: Selling crack in El Barrio". Cambridge: Cambridge University Press.

Buchanan, Julian. 2004. "Missing links? Problem drug use and social exclusion". Probation Journal: Journal of Community and Criminal Justice, 51(4), 387-397. http://dx.doi.org/10.1177/0264550504048246

Chambers, Robert. 1983. "Rural development: putting the last first". London: Longman.

Davis, Corey, Scott Burris, David Metzger, Julie Becher and Kara Lynch 2005. "Effects of an intensive street-level police intervention on syringe exchange programutilization: Philadelphia Pennsylvania". American Journal of Public Health, 3, 4, 210- 233.

Dillon, Lucy, Natalia Chivite-Matthews, Ini Grewal, Richar Brown, Stephen Webster, Emma Weddell, Geraldine Brown, and Nicola Smith, 2007. "Risk, protective factors and resilience to drug use: Identifying resilient young people and learning from their experiences". Home Office Online Report.

Fransiska, Asmin. 2010. "The future picture of Indonesian drug policy. Paper presented in Fourth Annual Conference of the International Society for the Study of Drug Policy". RAND Institute, Santa Monica, USA, 16 March.

Green, Judith and Nicki Thorogood. 2004. "Qualitative methods in health research". USA: Sage Publications.

Hawkins, John, Richard Catalano and Janet Miller. 1992. "Risk and protective factors for alcohol and other drug problems in adolescence and early adulthood: Implication for substance use prevention". Psychological Bulletin, 112(1), 64-105. http://dx.doi.org/10.1037/0033-2909.112.1.64 
Hunt, Geoffrey, Molley Moloney and Kristin Evans. 2010. "Youth, drugs, and nightlife". London \& New York: Routledge.

Hunt, Neil. 2006. "Young people and illicit drug use. In P. Aggleton, A. Ball, P. Mane (Eds), Sex, drug and young people". London and New York: Routledge.

Indonesian National Narcotics Board. 2013. "Estimate of the number of drug users in Indonesia". Jakarta. Unpublished document.

Indonesian National Narcotics Board. 2013. "Estimate of the number of drug users in Indonesia". Jakarta. Unpublished document.

International Drug Policy Consortium (2010). "Drug policy guide". IDPC.

Jahoda, Marie. 1981. "Work, employment, and unemployment: Values, theories, and approaches in social research". American Psychologist, 36, 184-191.

http://dx.doi.org/10.1037/0003-066X.36.2.184

Jahoda, Marie. 1997. "Manifest and latent functions. In N. Nicholson (Ed.), The Blackwell Encyclopedic dictionary of organisational psychology" (pp. 317-318). Oxford, England: Blackwell.

Kim, Irene and Nolan Zane. 2002. "Protective factors against substance use among Asian American youth: A test of the peer cluster theory". Journal of Community Psychology, 30(5), 565 - 584 http://dx.doi.org/10.1002/jcop.10022

Maher, Lisa. 2002. "Don't leave us this way: Ethnography and injecting drug use in the age of AIDS". International Journal of Drug Policy, 13(4), 311-325.

http://dx.doi.org/10.1016/S0955-3959(02)00118-4

Mayock, Paula. 2005. "'Scripting" risk: Young people and the construction of drug journey". Drugs: education, prevention and policy, 12(5), 349-368. http://dx.doi.org/10.1080/09687630500183020

Moore, David and Tim Rhodes. 2004. "Social theory in drug research, drug policy and harm reduction". International Journal of Drug Policy, 15(5), 323-325. http://dx.doi.org/10.1016/i.drugpo.2004.08.003

Nasir, Sudirman. 2006. "Drug subculture and the social context of HIVrisk behaviours among injecting drug users in a slum area (lorong) in Makassar, Indonesia". Unpublished Master thesis Melbourne School of Population Health. Unpublished thesis. Melbourne: the University of Melbourne.

Nasir, Sudirman. 2010. "Stories from the lorong: Drug use and non-drug use among young people in a slum area (lorong) in Makassar, Indonesia". Unpublished Ph.D thesis Melbourne School of Population Health. Unpublished thesis. Melbourne: the University of Melbourne.

Nasir, Sudirman and Doreen Rosenthal. 2009a. "The social context of initiation into injecting drugs in the slums of Makassar, Indonesia". International Journal of Drug Policy, 20, 237-243. http://dx.doi.org/10.1016/i.drugpo.2008.02.001

Nasir, Sudirman and Doreen Rosenthal. 2009b. "The lorong as a risk environment: drug use and gangs among young men in the slums of Makassar, Indonesia". Contemporary Drug Problems, 36, Spring-Summer, 193-215.

Nasir, Sudirman, Doreen Rosenthal and Timothy Moore. 2011. "The social context of controlled drug use amongst young people in a slum area in Makassar, Indonesia". International Journal of Drug Policy, 22, 463-470 http://dx.doi.org/10.1016/i.drugpo.2011.10.006

Paul, Karsten and Bernad Batinic. 2010. "The need for work: Jahoda's latent functions of employment in a representative sample of
German population". Journal of Organisational Behaviour, 31, 4564.

http://dx.doi.org/10.1002/job.622

Paul, Karsten and Klaus Moser. 2006. "Incongruence as an explanation for the negative mental health effects of unemployment: Metaanalytic evidence". Journal of Occupational and Organisational Psychology, 79, 595-621. http://dx.doi.org/10.1348/096317905X70823

Paul, Karsten and Klaus Moser. 2009. "Unemployment impairs mental health: Meta-analyses". Journal of Vocational Behaviour, 74, 264-282.

http://dx.doi.org/10.1016/i.jvb.2009.01.001

Putnam, Robert. 1993. "Making democracy work: Civic traditions in Italy". New Jersey: Princeton University Press.

Putnam, Robert. 2000. "Bowling Alone: The collapse and revival of American community". New York: Simon and Schuster.

Rivers, Kim, Peter Aggleton and Andrew Ball. 2006. "Young people, poverty and risk". In P. Aggleton, A. Ball, P. Mane (Eds), Sex, drug and young people. London and New York: Routledge.

Rhodes, Tim. 2009. "Risk environtment and drug harms: A social science for harm reduction approach". International Journal of Drug Policy, 20, 193-201. http://dx.doi.org/10.1016/j.drugpo.2008.10.003

Rhodes, Tim, Merryl Singer, Philippe Bourgois, Samuel Friedman and Stephanie Strathdee. 2005. "The social structural production of HIV risk among injecting drug users". Social Science and Medicine, 61, 1026-1044. http://dx.doi.org/10.1016/j.socscimed.2004.12.024

Rush, James. 2007. "Opium to Java: Revenue farming and Chinese enterprise in Colonial Indonesia, 1860-1910". Singapore: Equinox Publishing.

Sekulic, Damir, Radmila Kostic, Jelena Rodek, Vesna Damjanovic and Zdenko. 2008. "Religiousness as protective factors against substance use in dance sport". Journal of Religion and Health, 48(3), 269, 277.

Spooner, Caroline. 2005. "Structural determinants of drug use - A plea for broadening our thinking". Drug and Alcohol Review, 24, 89-92. http://dx.doi.org/10.1080/09595230500102566

Spreitzer, Gretchen and Scott Sonenshein. 2002. "Toward the construct definition of positive deviance. American Behavioural Scientists, 47(6), $215-219$.

Stevens, Alex. 2009. "Background noise: Drugs, poverty and equality". Paper presented in International Harm Reduction Conference, Bangkok, 23 April, 2009.

Tribun, Timur. 2013. "Menjual narkoba: Ibu rumah tangga ditangkap aparat. Hukum-Kriminalitas, Makassar" (Selling drugs: Housewives arrested). 12 January, 7.

UNAIDS. 2010. AIDS epidemic update. Joint United Nations program on HIVIAIDS. Geneva: UNAIDS.

Walburton, Hamish, Paul J. Turnbull and Mike Hough. 2005. "Occasional and controlled heroin use". London: Joseph Rowntree Foundation.

Woolcock, Michael. 2001. "The place of social capital in understanding social and economic outcomes". ISUMA Canadian Journal of Policy Research, 2(1), 11-17.

Woolcock, Michael and Anne Sweetser. 2002. Bright ideas: Social capital-The bonds that connect. ADB Review, 34, 2.

Received on 22-07-2014

Accepted on 18-09-2014

Published on 10-11-2014

DOI: http://dx.doi.org/10.6000/1929-4409.2014.03.29

(C) 2014 Nasir et al.; Licensee Lifescience Global.

This is an open access article licensed under the terms of the Creative Commons Attribution Non-Commercial License (http://creativecommons.org/licenses/by-nc/3.0/) which permits unrestricted, non-commercial use, distribution and reproduction in any medium, provided the work is properly cited. 